\title{
Co-opting the cooperative movement? Development, decolonization, and the power of expertise at the Co-operative College, 1920s-1960s ${ }^{\dagger}$
}

\author{
Mo Moulton* (i) \\ History Department, University of Birmingham, Birmingham, B15 2TT, UK \\ •Corresponding author. E-mail: m.moulton@bham.ac.uk
}

\begin{abstract}
Cooperative departments and organizations were a ubiquitous but rarely studied aspect of British colonial governance in the twentieth century. The Co-operative College in Britain provided specialized training in colonial cooperation to students from across the British Empire. The cooperative movement was a key part of the emergence of regimes of development in the decades between the 1920s and 1960s, reflecting their emphasis on modular solutions deployed by experts in an increasingly homogenizing 'developing world'. However, the colonial and post-colonial students at the Co-operative College were also critical of colonialism and capitalism, participating in the anti-colonial internationalist effort to create a more just postimperial world. As post-colonial governments retained cooperative structures, the former students of the Co-operative College used the movement as a counter-balance to the larger forces of nationalism and neo-colonialism.
\end{abstract}

Keywords: Cooperative movement; development; decolonization; education; expertise; internationalism

As one of the central dramas of twentieth-century history, decolonization works in both tragic and heroic modes. The dreams of anti-colonial world-makers, to borrow Adom Getachew's powerful term, conjured new horizons of possibility, but those possibilities were finally constrained by patterns of global postcolonial domination and exploitation that echoed and often replicated imperial hierarchies. ${ }^{1}$ Sovereignty was undone by neo-colonial incursions; the rupture insisted on by anticolonial thinkers was undone, too, by continuities between colonial and post-colonial regimes. Those who had tried to subvert the tools of colonialism risked being co-opted by them instead.

The focus of this article is the cooperative movement and in particular the colonial and postcolonial students who attended the Co-operative College, an institution of higher learning located first in Manchester and later in Loughborough, between 1920 and 1960. Taking the cooperative as a technology of both democracy and development, I find in its history a different account of power and resistance. Taking up development as a means to freedom, the students of the Co-operative College found, in the cooperative movement, a vantage point from which to challenge and revise both the old colonial order and the turn to centralized economic planning in the post-colonial state.

\footnotetext{
${ }^{\dagger}$ My sincere thanks to the three anonymous peer reviewers as well as John Munro, Samiksha Sehrawat, Manu Sehgal, my colleagues in the University of Birmingham History Department, and participants in the Cambridge Modern British History Seminar, for their comments and advice on this article. Thank you as well to the librarians and archivists at the National Co-operative Archive, Manchester, and the National Archives, London.

${ }^{1}$ Adom Getachew, Worldmaking after Empire: The Rise and Fall of Self-Determination (Princeton: Princeton University Press, 2019).

(C) The Author(s), 2021. Published by Cambridge University Press. This is an Open Access article, distributed under the terms of the Creative Commons Attribution licence (http://creativecommons.org/licenses/by/4.0/), which permits unrestricted re-use, distribution and reproduction, provided the original article is properly cited.
} 
Despite its ubiquity throughout the twentieth-century British Empire, the cooperative movement and the cooperative departments that became standard in colonial governments have received relatively little scholarly attention. Cooperatives were, at the simplest level, jointly owned resources governed by democratic committees. In the British context, the movement traced its origin to the consumer cooperatives pioneered in nineteenth-century Rochdale, which created a structure for working-class people to pool their resources and jointly run a shop to meet their needs. Elsewhere, cooperatives often focused on production: for example, the cooperative creameries that came to dominate butter production in Ireland. Although cooperatives were, in theory, local and self-contained, in practice they were supported and to some extent governed by overarching national organizations such as the British Co-operative Union and the Irish Agricultural Organisation Society as well as international bodies.

Spanning state and voluntary institutions and crossing national and imperial boundaries, the cooperative movement was also at the heart of the emerging development complex of the twentieth century. ${ }^{2}$ By mid-century, cooperative departments were nearly standard administrative components in British-held territories, and they were usually retained by postcolonial governments. These departments, together with allied cooperative organizations, oversaw networks of mostly agricultural and credit cooperatives that undertook activities ranging from lending money to farmers to arranging for the sale and marketing of commodities such as cocoa. In addition to their economic development goals, cooperatives were also cast as schools of democracy and incubators of modern citizenship. The cooperative movement was thus a key institution that gave form to the ideologies and practices of development that, as Ann Laura Stoler and Frederick Cooper have argued, were the main bridge between colonial and postcolonial governments. ${ }^{3}$

The students at the Co-operative College were actively involved in that process. They were part of what Christopher Dietrich has described as a global anti-colonial elite: able to mobilize resources to pursue higher education abroad, their encounters along the networks of imperial exchange forged the new internationalisms of the middle of the twentieth century. ${ }^{4}$ Like more celebrated figures such as George Padmore, C.L.R. James, and Kwame Nkrumah, they articulated a set of critiques that linked colonialism to capitalism and pointed toward a new international order. They were also civil servants and professionals whose expertise allowed them to use the cooperative movement to shape the postcolonial landscape of their countries.

In the first part of the article, I argue that the cooperative movement functioned as a core element of the developmental state. In part two, I turn to Co-operative College and the students who attended it from across the British Empire, situating them within the currents of interwar internationalism. As I explore in part three, the college was increasingly co-opted by the Colonial Office after the Second World War, becoming part of the nexus of official, semi-official, and philanthropic organizations that pushed the developmental agenda. Finally, in line with work that has refocused attention on bureacuracies as decisive arenas of decolonization, I close with three case studies featuring Co-operative College alumni in Sierra Leone, Malawi, and Ghana. Together, these cases suggest the diversity of uses to which cooperatives were put by late colonial and post-colonial regimes as well as the plural nature of development and democracy for its practitioners. ${ }^{5}$

\footnotetext{
${ }^{2}$ On transnational development regimes, see Subir Sinha, 'Lineages of the Developmentalist State: Transnationality and Village India, 1900-1965,' Comparative Studies in History and Society 50, no. 1 (2008): 57-90, 59.

${ }^{3}$ Ann Laura Stoler and Frederick Cooper, 'Between Metropole and Colony: Rethinking a Research Agenda,' in Tensions of Empire: Colonial Cultures in a Bourgeois World, eds. Frederick Cooper and Ann Laura Stoler (Berkeley: University of California Press, 1997), 36.

${ }^{4}$ Christopher R. W. Dietrich, Oil Revolution: Anticolonial Elites, Sovereign Rights, and the Economic Culture of Decolonization (Cambridge: Cambridge University Press, 2017), 7-8.

${ }^{5}$ Susan Pedersen, The Guardians: The League of Nations and the Crisis of Empire (Oxford: Oxford University Press, 2015), 46; Heather Sharkey, Living With Colonialism: Nationalism and Culture in the Anglo-Egyptian Sudan (Berkeley: University of California Press, 2003); Martin Maguire, The Civil Service and the Revolution in Ireland, 1912-38: 'Shaking the Blood-stained Hand of Mr Collins' (Manchester: Manchester University Press, 2008).
} 
Ultimately, cooperation is best understood as an ambivalent tool. In a now-classic formulation, Audre Lorde warned White feminists that 'the master's tools will never dismantle the master's house. ${ }^{\prime 6}$ It is possible to argue that, in picking up cooperative bureaucracy as a tool, postcolonial actors were engaging in that futile old effort of temporarily beating the oppressors at their own game of coercive governance. But cooperation was also more than that; it was a tool that had been forged in more than one place. Well designed for paternalism, it nonetheless consistently pulled its users back toward democratic process. Tracked through the careers of the Co-operative College alumni, the cooperative movement offers a new way to think about the complex relationship between British-based institutions, international movements, and the making of the postcolony.

\section{Cooperation as development}

The idea of organizing rural life and agricultural production by the means of formally constituted cooperatives emerged in the nineteenth century and gained global traction in the twentieth century. Although often allied with socialist thought and left-wing politics within interwar Britain, cooperatives found a role globally within a range of economic systems. ${ }^{7}$ Cooperation was an international phenomenon as well as an imperial one. ${ }^{8}$ The cooperative movement had global and international institutions dating back to the 1890s, when the International Co-operative Alliance (ICA) was founded in London. ${ }^{9}$ The policy of cooperation received encouragement from larger international bodies as well, including the International Institute of Agriculture in Rome and the World Economic Conference in Geneva. ${ }^{10}$

In territories under British administration, specialized legislation defined cooperatives and held them accountable to various standards and, often, centralized goals. From localized and often voluntary beginnings, agricultural cooperatives spread through the administrative apparatus of the British colonial empire in the 1920s and 1930s, part of an emerging focus on the problems of rural life in a globalizing agricultural market. ${ }^{11}$ In India, for example, a civil servant was sent to study cooperatives in Europe; his report spawned the creation, in the late nineteenth century, of a system of cooperative finance backed up by a cooperative bureaucracy in India and Ceylon, which became a model for the cooperative systems set up in other British territories. ${ }^{12}$

When Labour had been briefly in power in 1929-30, colonial secretary Lord Passfield tried to encourage cooperatives; this impulse returned with redoubled force in the wake of the endorsement of cooperation as economic policy at the United Nations Conference on Food and Agriculture in Hot Springs in 1943. ${ }^{13}$ The postwar Labour government institutionalized cooperative departments and their associated organizations and societies as a key part of its colonial policy. They fit well with Labour's commitment to economic planning and with the postwar

\footnotetext{
${ }^{6}$ Audre Lorde, 'The Master's Tools Will Never Dismantle the Master's House,' Sister Outsider: Essays and Speeches (Berkeley, Calif.: Crossing Press, 1984).

${ }^{7}$ See Matthew Hilton, Consumerism in Twentieth-Century Britain: The Search for a Historical Movement (Cambridge: Cambridge University Press, 2003), 36, 40, 80-4.

${ }^{8}$ Johnston Birchall, The International Co-operative Movement (Manchester: Manchester University Press, 1997).

${ }^{9}$ W. P. Watkins, The International Co-operative Movement: Its Growth, Structure and Future Possibilities (Manchester: Cooperative Union Ltd., no date), 16.

${ }^{10}$ Watkins, The International Co-operative Movement, 23-4; Co-operation in Other Lands II (Loughborough: Co-operative Union Limited, no date), 70.

${ }^{11}$ Harald Fischer-Tiné, 'The YMCA and Low-Modernist Rural Development in South Asia, c. 1922-1957,' Past \& Present 240 (Aug. 2018): 201, 213.

${ }^{12}$ Nikolay Kamenov, 'Imperial Cooperative Experiments and Global Market Capitalism, c.1900-c.1960', Journal of Global History 14, no. 2 (2019): 219-37, 224-26; Bimal Prasad Singh, Co-operatives and Development: A Political Study (Delhi: Devika Publications, 2003).

${ }^{13}$ Young, Sherman, and Rose, Cooperatives and Development, 10; Kelemen, “'Individualism is, Indeed, Running Riot”,' 191; Watkins, The International Co-operative Movement, 24; Co-operation in Other Lands II, 70.
} 
economic importance of the empire in stabilizing currency. ${ }^{14}$ And they would prove a durable component of the postwar economic restructuring of colonial economies, playing a central role in the large, state-run projects in agricultural commodities that were important to what has been described as the 'second colonial occupation' of postwar Africa. ${ }^{15}$

In 1945, the Fabian Colonial Bureau published a report from a special committee on cooperation. The report echoed left-wing critiques of extractive colonialism that benefitted a few European and American firms. ${ }^{16}$ Using cooperatives as a tool for economic development, by contrast, the report argued, would allow small producers to participate efficiently in a world that would be shaped by 'increasing international control of production and marketing of primary products' as well as by 'commodity and price control boards. ${ }^{\prime 7}$ The report linked cooperation to eventual national self-determination, but insisted that small cultivators in the colonies would need government assistance in establishing cooperation as part of the larger 'transition from the old to the new economy. ${ }^{18}$ To this end, the report outlined the creation of a systematic bureaucracy, centered on a Co-operative Department and Co-operative Advisory Committee in the Colonial Office which would provide direction to the corresponding Co-operative Department and Registrar in each colony; the overall direction of cooperatives in colonies should remain in the hands of the colonial administration, the report argued, rather than being delegated to native authorities or rulers. ${ }^{19}$ The result was a very rapid expansion in cooperative societies across British territories. By the second half of the 1950s, the Co-operative Union counted over nine thousand registered co-operative societies in twenty colonial territories, representing over one million members. ${ }^{20}$ This expansion also represented a certain standardization, as the structures and goals of cooperative organization transformed into a replicable model.

At its core, the cooperative movement was a technology of development, centred on the modular solution of the small-scale cooperative that promised to transform human as well as agricultural capital. ${ }^{21}$ Cooperatives were popular among policy-makers because they promised to address some of the core problems of colonial governance. ${ }^{22}$ Like all such modular solutions, cooperation homogenized its target, fashioning the varied agricultural societies around the world as essentially commensurable and able to be reformed through the deployment of a standardized set of cooperative practices. $^{23}$ The practices aimed to achieve a set of related goals.

\footnotetext{
${ }^{14}$ Richard Toye, The Labour Party and the Planned Economy 1931-1951 (Woodbridge: Boydell, 2003); Noel Thompson, Political Economy and the Labour Party: The Economics of Democratic Socialism, 1884-2005 (2 ${ }^{\text {nd }}$ edition. London \& New York: Routledge, 2006), 2-3; Gerold Krozewski, Money and the End of Empire: British International Economic Policy and the Colonies, 1947-58 (London: Palgrave, 2006), 9.

${ }^{15}$ John McCracken, A History of Malawi 1859-1966 (Boydell \& Brewer, 2012), 237; Kelemen, “'Individualism is, Indeed, Running Riot",' 193; Hodge, Triumph of the Expert, 13-4.

${ }^{16}$ Fabian Society Colonial Bureau, Co-operation in the Colonies: A Report from a Special Committee to the Fabian Colonial Bureau (London: George Allen \& Unwin Ltd., 1945), 18, 21.

${ }^{17}$ Fabian Society Colonial Bureau, Co-operation in the Colonies, 16.

${ }^{18}$ Fabian Society Colonial Bureau, Co-operation in the Colonies, 14-5.

${ }^{19}$ Fabian Society Colonial Bureau, Co-operation in the Colonies, 166-67, 176.

${ }^{20}$ Memorandum on Co-operation in the Non-Self-Governing Territories under United Kingdom Administration, CO 852/ 1360/1, and 'Advisory Committee on Co-operation in the Colonies,' 7 March 1950, CO 852/1360/5, National Archives, London (henceforth NA); Co-operation in Other Lands II, 75.

${ }^{21}$ Nicole Sackley, 'Village Models: Etawah, India, and the Making and Remaking of Development in the Early Cold War,' Diplomatic History 37, no. 4 (2013), 755.

${ }^{22}$ Aaron Windel, 'Mass Education, Cooperation, and the "African Mind”', in Modernization as Spectacle in Africa, eds. Peter J. Bloom, Stephan F. Miescher, and Takyiwaa Manuh (Bloomington: Indiana University Press, 2014), 89-111, 89; Patrick Develtere, Co-operation and Development with Special Reference to the Experience of the Commonwealth Caribbean (Leuven: Acco, 1994), 48; Frederick Cooper, 'Reconstructing Empire in British and French Africa,' Past \& Present (2011), Supplement 6, 198-99; Joseph Morgan Hodge, Triumph of the Expert: Agrarian Doctrines of Development and the Legacies of British Colonialism (Athens, Ohio: Ohio University Press, 2007), 2-3.

${ }^{23}$ Arturo Escobar, Encountering Development: The Making and Unmaking of the Third World (Princeton: Princeton University Press, 1995); Corrie Decker and Elisabeth McMahon, The Idea of Development in Africa: A History
} 
Cooperation was meant to provide, not only greater economic efficiency, but a transformation of cooperative society members into modern economic citizens who could participate efficiently in a globalized market economy while bearing the 'burden of redemption' themselves, in Atiyab Sultan's words. ${ }^{24}$ According to the logic of the cooperative model, the very act of participating in sharing and governing a pooled resource would fundamentally change individuals and, by extension, their societies. The 1915 Committee on Cooperation in India, presided over by Sir E. D. Maclagan, asserted that cooperation would allow 'weak individuals' to 'improve their individual productive capacity and consequently their material and moral position, by combining among themselves and bringing into this combination a moral effort and a progressively developing realization of moral obligation. ${ }^{25}$ This could even include the moral obligation to embrace growthoriented capitalism. Hubert Calvert, the registrar of co-operative societies in Punjab, argued in 1926 that, while most Indian people thought in a way that was 'essentially uneconomic,' the cooperative movement could help peasants to be re-educated to seek growth and improvement above all. ${ }^{26}$

Yet for all that cooperatives were imagined as a training for citizenship, they occupied an ambivalent position with respect to democratic politics. At the local level, cooperatives were part of a broader interest in using communities, frequently in the form of villages, as vehicles for remaking societies, particularly in colonial or postcolonial settings. ${ }^{27}$ Although they might be romanticized as natural or ancient, such communities were fundamentally political. ${ }^{28}$ Cooperatives, as features of village life or as communities in their own right, were based on an ideal individual, frequently an autonomous male individual, who was capable of owning shares, casting votes, and pursuing economic self-interest. Yet that individual came into being only through being firmly bound within the cooperative form, which would facilitate collective development as well as the individual's transformation into a more modern and more moral citizen.

However, like later development projects, cooperation in colonized spaces was also imagined as an alternative to politics. ${ }^{29}$ Colonial cooperation was routinely described as a safer, more stable route to modernity than 'detribalization' or nationalism. ${ }^{30}$ As Steven Feierman has argued, it was the economic wing of the idea of indirect rule: simultaneously a halfway house to independence and a method of trying to retain often idealized social hierarchies and traditional arrangements in rural areas. ${ }^{31}$ Lord Lugard explicitly linked cooperation with indirect rule: both, he said, aimed 'to teach personal responsibility and initiative' as a means of addressing the problem of 'an increasingly large illiterate class which by prolonged contact with alien races has learnt a new individualism without its necessary restraints. ${ }^{32}$ Such ideas made their way directly into the developing

(Cambridge: Cambridge University Press, 2020); David Arnold, 'Agriculture and 'Improvement' in Early Colonial India: A Pre-History of Development,' Journal of Agrarian Change 5, no. 4 (Oct. 2005), 505-25, 510; Patricia Clavin, Securing the World Economy: The Reinvention of the League of Nations, 1920-1946 (Oxford: Oxford University Press, 2013), 8; Manu Goswami, 'Imaginary Futures and Colonial Internationalism,' American Historical Review (December 2012), 1464; Samantha Iyer, 'Colonial Population and the Idea of Development,' Comparative Studies in Society and History 55, no. 1 (Jan. 2013), 65-91, 68.

${ }^{24}$ Sultan, 'Malcolm Darling and Developmentalism in Colonial Punjab,' 1892.

${ }^{25}$ Report of the Committee on Co-operation in India (Simla: Government Press, 1915), $\mathrm{x}$.

${ }^{26}$ Proceedings of the Ninth Conference of Registrars of Co-operative Societies in India, pp. 7-8.

${ }^{27}$ Nicole Sackley, 'The Village as Cold War site: Experts, Development, and the History of Rural Reconstruction,' Journal of Global History 6 (2011): 481-504, 503.

${ }^{28}$ Sinha, 'Lineages of the Developmentalist State,' 84.

${ }^{29}$ James Ferguson, The Anti-Politics Machine: 'Development,' Depoliticization, and Bureaucratic Power in Lesotho (Minneapolis: University of Minnesota Press, 1994 [1990]); Peter Uvin, Aiding Violence: The Development Enterprise in Rwanda (West Hartford, CT: Kumarian Press, 1998).

${ }^{30}$ See Strickland, Co-operation in India, 3, 68; Strickland, Co-operation in Africa, 2.

${ }^{31}$ Steven Feierman, Peasant Intellectuals: Anthropology and History in Tanzania (Madison: University of Wisconsin Press, 1990), 233.

${ }^{32}$ Introduction by Lord Lugard, Strickland, Co-operation in Africa, vii, ix. 
cooperative bureaucracies in the colonies. The administrator in charge of cooperation in Malaya, Alexander Cavendish, explicitly admitted his own debt to Lugard's Dual Mandate, which he described as 'the book that guides all administrators. ${ }^{33}$

Although cooperatives were often closely connected with state initiatives around the world, colonial cooperative movements were often singled out as being especially dependent on government direction. ${ }^{34}$ In other words, true, 'voluntary' cooperative movements were linked with Europeans, while state-run cooperative movements were linked with colonized populations in need of tutelage in the ways of modern economic citizenship. ${ }^{35}$ Proposing the introduction of cooperatives to British Africa, C. F. Strickland distinguished the Indian model he hoped to import for Africans from existing 'co-operative societies for Europeans'. ${ }^{36}$ In India itself, increasing powers were granted to registrars and other officials in the cooperative movement, which was often seen as inseparable from the government. ${ }^{37}$ A survey in 1915 found, for example, that people were not clear whether the loans from cooperative societies were guaranteed by the government. ${ }^{38}$

Colonial cooperation also provided terrain for the development of new forms of expertise, as British colonial experts promoted cooperatives both within and beyond the empire and, in so doing, re-fashioned themselves from area hands into 'the globetrotting expert'. ${ }^{39}$ Sir Malcolm Darling began his career an expert in Punjab with an interest in rural life; he became, through travels and writing, an expert in cooperation with prominent positions including a seat on the Colonial Office's Advisory Committee on Co-operation in the Colonies. ${ }^{40}$ W.K.H. Campbell, a joint registrar of Co-operative Societies in Ceylon, was one of three 'experts in rural cooperative societies' sent by the League of Nations to China in $1933 .{ }^{41}$ And C. F. Strickland's twelve years' service as a Registrar of Co-operative Societies in India launched his subsequent career as a kind of cooperative expert for hire in Africa and Asia. He taught for a time at the University of Nanking and wrote several several influential, wide-ranging texts on cooperation. ${ }^{42}$

\footnotetext{
${ }^{33}$ Imperial Conference on Agricultural Co-operation: Report of Proceedings (London: P.S. King \& Sons, Ltd., 1938), $192-93$.

${ }^{34}$ Daniel T. Rodgers, Atlantic Crossings: Social Politics in a Progressive Age (Cambridge, Mass.: Belknap Press, 1998), 320-55; Abby Spinak, 'Infrastructure and Agency: Rural Electric Cooperatives and the Fight for Economic Democracy in the United States,' PhD thesis, Massachusetts Institute of Technology, Feb. 2014.

${ }^{35}$ See Ushnish Sengupta, 'Indigenous Cooperatives in Canada: The Complex Relationship between Cooperatives, Community Economic Development, Colonization, and Culture,' Journal of Entrepreneurial and Organizational Diversity 4, no. 1 (2015): 121-52, 137, 140-41.

${ }^{36}$ Strickland, Co-operation in Africa, 1.

${ }^{37}$ Eleanor M. Hough, The Co-operative Movement in India, 5th edn. (Oxford: Oxford University Press, 1966), 25-6, 50, 331; Proceedings of the Ninth Conference of Registrars of Co-operative Societies in India (Calcutta: Government of Central Publication Branch, 1926), 2; Strickland, Co-operation in India, 59; S. K. Yegnanarayana Aiyar, 'Co-operative India: A Survey of Progress,' Year Book of Agricultural Co-operation, 1930 (London: George Routledge and Sons, Ltd., 1930 ), 205.

${ }^{38}$ Report of the Committee on Co-operation in India, 1, 125 [quote].

${ }^{39}$ Atiyab Sultan, 'Malcolm Darling and Developmentalism in Colonial Punjab,' Modern Asian Studies 51, no. 6 (2017): 1891-1921, 1894 (quote); Kamenov, 'Imperial Cooperative Experiments and Global Market Capitalism,' 220.

${ }^{40}$ Sultan, 'Malcolm Darling and Developmentalism in Colonial Punjab,' 1897, 1904; Kamenov, 'Imperial Cooperative Experiments and Global Market Capitalism,' 228; Nikolay Kamenov, 'The Place of the 'Cooperative' in the Agrarian History of India, c. 1900-1970,' The Journal of Asian Studies (2019), 21.

${ }^{41}$ Margherita Zanasi, 'Exporting Development: The League of Nations and Republican China,' Comparative Studies in Society and History 49, no. 1: 2007, 143-69, 143; Kamenov, 'Imperial Cooperative Experiments and Global Market Capitalism,' 223; C. F. Strickland, Co-operation in India: A Students' Manual, $3^{\text {rd }}$ edition (Mysore: Oxford University Press, 1938), 38n1, 39, 56.

${ }^{42}$ Introduction by Lord Lugard, C. F. Strickland, Co-operation in Africa (London: Oxford University Press, 1933), vii; Kamenov, 'Imperial Cooperative Experiments and Global Market Capitalism,' 229; Johanna Värlander, 'A Genealogy of Governing Economic Behaviour: Small-scale credit in Malawi 1930-2010,' PhD thesis, Uppsala Studies in Economic History 97 (2013), 58.
} 
But colonial cooperation was never only a disciplinary machine that squashed politics and promoted British expertise. ${ }^{43}$ The story of the Gold Coast cocoa cooperatives is exemplary. By the 1920s, the dynamic Gold Coast cocoa industry was the scene of African economic participation, including 'proto-cooperatives'. ${ }^{44}$ This attracted the attention of the colonial government, which sent an expert to Ceylon and Madras to study the cooperative movements there. ${ }^{45}$ Through the Co-operative Societies Ordinance in 1931, the Gold Coast government tried to bring cooperatives within an official structure. ${ }^{46}$ This tight new control lessened the appeal of the cooperatives to farmers, however, and the Agriculture Department was obliged to balance centralizing moves with other improvements that led, in turn, to the re-emergence of more assertive, autonomous cooperatives. ${ }^{47}$ In 1937-38, these cooperatives were crucially involved in the cocoa 'holdups' that challenged the price-fixing efforts of nearly all the European firms. ${ }^{48}$ Such activity reveals cooperatives as potent actors within the larger economic and political scene.

\section{Co-operative internationalists}

The students of the Co-operative College occupied a different space: neither globe-trotting experts nor agricultural producers themselves, they travelled to Britain to further both bureaucratic careers and world-making ambitions. The Co-operative College grew out of the broader educational activities of the British Co-operative Union, which ranged from technical training for employees of cooperatives to evening classes and lecture series for members. Fred Hall, the adviser of studies at the Co-operative Union, founded the College in 1919 as a kind of 'apex organization' for this activity. ${ }^{49}$ Students at the College took classes at a central location in Manchester and lived in hostels in Manchester suburbs. Initially Hall did nearly all of the teaching, but the numbers of students and teachers expanded gradually; by 1938, there were fifteen teachers in addition to administrative staff. ${ }^{50}$ Most of the College's students came from the British cooperative movement and used the training they received to take on more advanced work within cooperative societies, as managers, secretaries, and organizers, or within national cooperative organizations, as Hall himself explained in $1928 .^{51}$

From the beginning, the College also educated students from overseas, including from Britain's colonial territories. They can be usefully situated in several contexts. Some were training for roles within colonial administrations and might be seen as part of the broader empire-wide educational

\footnotetext{
${ }^{43}$ Paul Kelemen, “'Individualism is, Indeed, Running Riot”: Components of the Social Democratic Model of Development,' 188-201, in Empire, Development and Colonialism: The Past in the Present, eds. Mark Duffield and Vernon Hewitt (Woodbridge: James Currey, 2009), 195.

${ }^{44}$ Crawford Young, Neal P. Sherman, and Tim H. Rose, Cooperatives and Development: Agricultural Politics in Ghana and Uganda (Madison: University of Wisconsin Press, 1981), 177; Kamenov, 'Imperial Cooperative Experiments and Global Market Capitalism,' 231; Sarah Stockwell, The Business of Decolonization: British Business Strategies in the Gold Coast (Oxford: Clarendon Press, 2001), 33-5.

${ }^{45}$ Kamenov, 'Imperial Cooperative Experiments and Global Market Capitalism,' 29.

${ }^{46}$ Young, Sherman, and Rose, Cooperatives and Development, 177-78. See Marvin P. Miracle and Ann Seidman, Agricultural Cooperatives and Quasi-Cooperatives in Ghana, 1951-1965 (Madison, Wisc.: University of Wisconsin Land Tenure Center, July 1968), 5-7; Strickland, Co-operation in Africa, 51.

${ }^{47}$ Young, Sherman, and Rose, Cooperatives and Development, 177-78.

${ }^{48}$ Jeffrey S. Ahlman, Living with Nkrumahism: Nation, State, and Pan-Africanism in Ghana (Athens: Ohio University Press, 2017), 133; Miracle and Seidman, Agricultural Cooperatives and Quasi-Cooperatives in Ghana, 7n22.

${ }^{49}$ Tom Woodin, 'Co-operation, Leadership and Learning: Fred Hall and the Co-operative College before 1939,' in Mass Intellectuality and Democratic Leadership in Higher Education, eds. Joss Winn, Richard Hall, Camilla Erksine, Jon Nixon, and Tanya Fitzgerald (London: Bloomsbury, 2017), 27-40, 27-9 (quote 29).

${ }^{50}$ Robert Snowball Birch, 'The Story of the Co-operative College,' The Stokehole (1944): 4-5.

${ }^{51}$ Woodin, 'Co-operation, Leadership and Learning,' 38, citing Fred Hall, The Co-operative College and Its Work (Manchester: Co-operative Union, 1928), 7.
} 
machine that produced civil servants, clerks, and other bureaucratic workers. ${ }^{52}$ Equally, the College was part of a wider phenomenon of educational institutions in this era that sought to mould cadres of activists for social change working across borders. Parallels can be drawn with the Soviet Union's contemporary Communist University for the Toilers of the East, even as the College's focus on applied research and policy recommendations placed it within a field of 'scientific research on society' increasingly funded by American philanthropic organizations. ${ }^{53}$ Perhaps the closest analogy would be with the Bible and missionary colleges that educated Christian students from around the world. The College's graduates preached the gospel of cooperation, often with a genuinely evangelical fervour, and their approach chimed with the contemporary proto-development work of missionaries themselves. ${ }^{54}$ Finally, they were part of the broader networks of Black and Asian students in interwar Britain, whose anti-colonial resistance was rooted both in Communism and liberal internationalism. ${ }^{55}$

Unlike globe-trotting experts such as Darling or Strickland, the students who arrived at the Co-operative College from Africa, Asia, and the Caribbean were expected to be local leaders and vectors for the propagation of the movement. Although comprehensive student records are not available, I constructed a database of students from former and current British colonies using cooperative periodicals, student newspapers, and scholarship documents. I identified thirtyfive students who came from British colonies to the Cooperative College before 1945. The majority (twenty-three) came from India; six came from Egypt, two each from Sierra Leone and South Africa, and one each from British Guiana and Ceylon. ${ }^{56}$

Studying such students offers one way to move the history of colonial expertise beyond an emphasis on the replacement of the (White) area specialist with the (White) neocolonial roving subject specialist. ${ }^{57}$ The students of the Co-operative College often took posts in colonial bureaucracies as policies of Indianization or Africanization slowly transformed the colonial civil service, in a moment when such bureaucracies were contributing to the development practices and expertise. ${ }^{58}$ The Co-operative College's colonial students deployed their expertise in a range of decolonizing contexts beyond the White-dominated circuit of development expertise. Studying their careers thus expands our understanding of the networks of knowledge that underpinned both colonial knowledge production and anticolonial and postcolonial thought as well. ${ }^{59}$

\footnotetext{
${ }^{52}$ Sharkey, Living with Colonialism, 40-65; Sumita Mukherjee, Nationalism, Education, and Migrant Identities: The England-Returned (London: Routledge, 2010); Inderpal Grewal, 'The Masculinities of Post-colonial Governance: Bureaucratic memoirs of the Indian Civil Service,' Modern Asian Studies 50, no. 2 (2016), 602-35.

${ }^{53}$ Carolien Stolte, 'Uniting the Oppressed Peoples of the East: Revolutionary Internationalism in an Asian Inflection,' in Ali Raza, Franziska Roy, and Benjamin Zachariah, The Internationalism Moment: South Asia, Worlds, and World Views, 1917-39 (London: Sage Publications, 2015), 68; Robert A. Paul, 'Colonialism, Capital, and the Rise of the Structural-Functionalist School of British Anthropology,' History and Anthropology 27, no. 2 (2016) 210-29, 226 (quotation); Freddy Foks, 'Bronislaw Malinowski, 'Indirect Rule,' and the Colonial Politics of Functionalist Anthropology, ca. 1925-1940,' Comparative Studies in Society and History 60, no. 1 (2018), 35-57.

${ }^{54}$ Rajsekhar Basu, 'Missionaries as Agricultural Pioneers: Protestant Missionaries and Agricultural Improvements in Twentieth-Century India,' 99-121, in Deepak Kumar and Bipasha Raha, eds, Tilling the Land: Agricultural Knowledge and Practices in Colonial India (Delhi: Primus Books, 2016); Peter Kallaway, 'Diedrich Westermann and the Ambiguities of Colonial Science in the Inter-War Era,' Journal of Imperial and Commonwealth History 45, no. 6 (2017), 871-93, 881; Fischer-Tiné, 'The YMCA and Low-Modernist Rural Development in South Asia'; Sackley, 'Village Models,' 755.

${ }^{55}$ Minkah Makalani, In the Cause of Freedom: Radical Black Internationalism from Harlem to London, 1917-1939 (Chapel Hill: The University of North Carolina Press, 2011); Marc Matera, Black London: The Imperial Metropolis and Decolonization in the Twentieth Century (Oakland: University of California Press, 2015).

${ }^{56}$ May Goulding, '1919 and All That,' Co-operative College Magazine 1953, 7; W. P. Watkins, 'The College and its International Influence,' Co-operative College Magazine 1952, 9.

${ }^{57}$ Hodge, Triumph of the Expert, 12; Timothy Mitchell, Rule of Experts: Egypt, Techno-Politics, Modernity (Berkeley: University of California Press, 2002).

${ }^{58}$ Värlander, 'A Genealogy of Governing Economic Behaviour,' 57.

${ }^{59}$ Benoit Daviron, 'Mobilizing Labour in African Agriculture: The Role of the International Colonial Institute in the Elaboration of a Standard of Colonial Administration, 1895-1930,' Journal of Global History 5 (2010), 479-501; Volker
} 
As an institution, the College saw itself as a microcosm of the change it sought to make in the world: an international space in which members cooperated for the greater good, but also a space of transformation. Many internationalists saw struggles against oppression around the world as essentially linked. ${ }^{60}$ At the same time, supporters of the cooperative movement saw it as naturally in tune with internationalism-Leonard Woolf, for example, linked consumer cooperatives to world peace. ${ }^{61}$ In this vein, the student newspaper recorded the College's 'cosmopolitan, yet friendly atmosphere. ${ }^{\prime 62}$ A typical tram journey from hostel to class in 1929 featured each student 'reading his or her own national newspaper printed in the native language. The Japanese reading that great, and, to us, unintelligible sort of shorthand which he says is Japanese news. Our Egyptian friend sits beside the Japanese student with a paper printed in a somewhat similar, and, let us add, equally unintelligible language. ${ }^{63}$ Rendering Japanese and Arabic as commensurable and unknowable, this editorial indulges in a fairly superficial kind of cosmopolitanism. In the more troubled years of the 1930s, however, the student newspaper argued seriously for the importance of the College's overseas students, whose presence 'accentuates its co-operative character, especially at a time of international crisis. ${ }^{\text {'64 }}$

How did colonial students themselves make use of the College? The experience of Egyptian students is illustrative: they strategically and often critically took elements of the cooperative model to inform a nationally specific development programme. Having already built a relationship with the Irish cooperative movement, Ibrahim Rashad was at the College in 1924. He would become the head of the Co-operative Section in the Egyptian Department of Agriculture. ${ }^{65}$ In his role as architect of cooperation for the Egyptian government, he made use of the Co-operative College's resources, with the result that numerous Egyptian students attended the College throughout the 1920s and 1930s. ${ }^{66}$ For example, the Egyptian government sent A.L.F. Amer to spend two years there in 1928-30. ${ }^{67}$ Writing for The Co-operative Educator, Amer introduced his country in classic Orientalist terms: 'Egypt is a country of romance.... In Egypt the old and the new are inextricably blended.' The rest of the article, however, briskly described the development and setbacks of cooperative legislation. ${ }^{68}$ Amer was probably also the anonymous Egyptian student quoted in the student magazine in 1929 arguing that citizens of other places should be strategic rather than deferential in learning from British success, making 'use of their civilization' rather than 'copying their police regulations and idle bureaucratic systems. ${ }^{69}$ Amer was Sub-Director of the Co-operative Department in Cairo by 1947 and Director-General of the Co-operative Department by $1955 .^{70} \mathrm{He}$ was part of what Omnia El Shakry describes as a 'social-

Barth and Roland Cvetkovski, eds., Imperial Co-operation and Transfer, 1870-1930: Empires and Encounters (London: Bloomsbury Academic, 2015); Benjamin Zachariah, 'Internationalisms in the Interwar Years: The Traveling of Ideas,' in Raza, Roy, and Zachariah, The Internationalism Moment.

${ }^{60}$ Makalani, In the Cause of Freedom, 4; John Munro, The Anticolonial Front: The African American Freedom Struggle and Global Decolonisation, 1945-1960 (Cambridge: Cambridge University Press, 2017), 4.

${ }^{61}$ Hilton, Consumerism in Twentieth-Century Britain, 84; Mary Hilson, 'The consumer co-operative movement in crossnational perspective: Britain and Sweden, c. 1860-1939,' 69-85, in Consumerism and the Co-operative Movement in Modern British History: Taking Stock, eds. Lawrence Black and Nicole Robertson (Manchester: Manchester University Press, 2009), 81; Andrew Flinn, "Mothers for Peace", Co-operation, Feminism and Peace: The Women's Co-operative Guild and the Anti-War Movement between the Wars,' 138-56, in Consumerism and the Co-operative Movement, eds. Black and Robertson, 151.

${ }^{62 ‘ C h a i r m a n ' s ~ R e m a r k s, ' ~ T h e ~ S t o k e h o l e ~(J u n e ~ 1933), ~} 2$.

${ }^{63}$ The Stokehole (March 1929), 1.

${ }^{64 ‘}$ Editorial,' The Stokehole (March 1932), 1.

${ }^{65}$ Ahmad Shokr, 'Beyond the Fields: Cotton and the End of Empire in Egypt, 1919-1956,' PhD thesis, New York University (May 2016); The Co-operative Educator 9, no. 1 (April 1927), 18.

${ }^{66}$ I. Khalil, 'Bank Misr (Egypt),' The Stokehole (1938), 62; A. D. Touny, 'Palestine,' The Stokehole (1939).

${ }^{67}$ The Co-operative Educator 14, no. 4 (Oct. 1930): 128.

${ }^{68}$ A. L. F. Amer, 'Modern Egypt,' The Co-operative Educator 13, no. 1 (Feb. 1929): 20-23.

${ }^{69}$ An Egyptian, 'The English Mind and Character,' The Stokehole (March 1929), 12 (first quote), 18 (second quote).

${ }^{70 ‘}$ 'College Notes,' The Co-operative Educator 15, no. 1 (Jan. 1931): 29; A. L Amer, 'Co-operative Societies in Egypt,' Review of International Co-operation (1947), 163-66; A. L. Amer, 'Egypt,' Yearbook of Agricultural Cooperation (1955). 
scientific program' run by the 'Indigenous nationalist elite' to demonstrate that Egyptian peasants were both unique and able to be educated. ${ }^{71}$ This work launched a wave of rural reform that was seen by its participants as effective and successful at fostering participation. ${ }^{72}$

While leading experts framed colonial cooperation as an alternative to nationalist politics, the students of the College increasingly replaced this narrative with a broader critique of colonial political economy. Some echoed the standard line. Khalibur Rahman, a lecturer at the Bihar \& Orissa Co-operative Institute who attended the College in 1931-32, argued that nationalists like Mahatma Gandhi were merely exploiting economic problems, while a cooperative movement could solve them, concluding that the 'road to real self-government lies through the thorny path of rural co-operative organisation. ${ }^{73}$ But more often, students argued that cooperation offered not a road to democratic citizenship in a capitalist market economy, but an alternative to capitalism itself. $^{74}$ In 1938, J. V. P. da Silva, an anti-colonial activist as well as a student at the College, offered a scathing critique of the oppressive British imperial state in Ceylon, which suppressed basic freedoms and enforced low wages and living standards in order to protect British capital investments in rubber and tea plantations. ${ }^{75}$ Likewise, Egyptian A. D. Touny argued that Zionism in Palestine was 'a colonisation that rests today on the British Military Forces for the cause of International Capitalism and Slavery. ${ }^{76}$ Such analysis chimes with the contemporary broader Black internationalism that linked economic transformation with the creation of a more just post-colonial world order. $^{77}$

With the approach of the Second World War, fewer non-British students attended the Cooperative College. In November 1939, there were five: one from Denmark, one from India, one from South Africa, and two men who were described as being from Ethiopia, T. Ras Makonnen and Laminah Sankoh. ${ }^{78}$ In fact neither Makonnen nor Sankoh was from Ethiopia. Instead, they were Pan-Africanists who saw cooperation as an important part of the transformation of economics and society that should follow independence.

Born George T. N. Griffith to a gold and diamond miner in British Guiana, Makonnen had studied in the United States and Denmark before arriving in London. ${ }^{79} \mathrm{He}$ traced his interest in the cooperative movement to his youth and his early adulthood. In British Guiana, rural people pooled their resources in order to buy land after emerging from slavery with no savings, a practice he linked etymologically to West African culture. ${ }^{80}$ Makonnen distinguished these efforts from the formal cooperative movement he enountered via accounts in 'the Negro press' while working in Texas, which fired his imagination but had not yet developed into a concrete movement. ${ }^{81}$ In London, he was deeply involved in Black internationalist politics, particularly International

\footnotetext{
${ }^{71}$ Omnia El Shakry, The Great Social Laboratory: Subjects of Knowledge in Colonial and Postcolonial Egypt (Stanford: Stanford University Press, 2007), 6 [quote], 114-24.

${ }^{72}$ Amy J. Johnson and Amanda L. Johnson, 'Re-Evaluating Egyptian History: A Critical Re-Examination of Rural Development Policy, 1940-2000,' Middle Eastern Studies 42, no. 1 (2006): 21-47.

${ }^{73} \mathrm{~K}$. Rahman, 'A New Phase of Co-operation in India,' The Stokehole (March 1932), 26.

${ }^{74}$ See Bruno Jossa, 'Marx, Lenin and the Cooperative Movement,' Review of Political Economy 26, no. 2 (2014): $282-302$.

${ }^{75}$ J. V. P. da Silva, 'The Simplicity of Britain's Public Mind,' The Stokehole (1938), 35-6 [quote 35]. See Priyamvada Gopal, Insurgent Empire: Anticolonial Resistance and British Dissent (London: Verso, 2019), 383.

${ }^{76}$ A. D. Touny, 'Palestine,' The Stokehole (1939), 24.

${ }^{77}$ Makalani, In the Cause of Freedom, 15.

${ }^{78 ،}$ Co-operative College Students,' The Co-operative Review 13, no. 11 (Nov. 1939): 381.

${ }^{79}$ Hakim Adi and Marika Sherwood, Pan-African History: Political Figures from Africa and the Diaspora since 1787 (London: Routledge, 2003), 117-18.

${ }^{80}$ Ras Makonnen, Pan-Africanism from Within, as recorded and edited by Kenneth King (Nairobi: Oxford University Press, 1973), 5-6.

${ }^{81}$ Makonnen, Pan-Africanism from Within, 92. See Jessica Gordon Nembhard, Collective Courage: A History of African American Cooperative Economic Thought and Practice (University Park: Pennsylvania State University, 2014).
} 
African Service Bureau (IASB). ${ }^{82}$ The IASB's offices were 'just round the corner' from the Co-operative Union office, and Makonnen got to know such movement leaders as C.F. Strickland, Margaret Digby, and Lord Rusholme. When he moved north, these friends gave him contacts in the movement there. ${ }^{83}$ In Manchester, he became involved with the Co-operative College; he is described as a student there in 1939, though in his memoir he focuses on the public lecturing he undertook on the subject. He also ran restaurants, clubs, and rental properties that provided a rich venue for Black British social life and helped to fund an array of activist efforts. ${ }^{84}$

Sankoh's trajectory was similar. Born Ethelred Nathaniel Jones, he studied theology and philosophy at Oxford University but was so appalled at the racism he enountered while trying to be ordained that he changed his name to Lamina Sankoh. Although he returned briefly to Sierra Leone in the 1920s, he soon embarked on an interinent life that brought him to key nodes of the black internationalism: teaching at the Tuskegee Institute, for example, and, after returning to England in 1930, becoming active in the West African Studies Union, where he served as an editor to the organisation's journal. ${ }^{85} \mathrm{He}$ 'was so impressed with what he heard of the cooperative movement from friends' that he decided to undertake a course at the Co-operative College. ${ }^{86}$ There, he advocated for a cooperative movement in Sierra Leone as a prelude to politics: it would, he argued, 'give the people economic security and provide a training ground in democratic principles.' However, he sharply criticized the 'inexcusable' 'lack of knowledge' on the part of average British people about 'conditions of the Colonial Empire,' for which they were, ultimately, responsible. ${ }^{87}$

In public talks at women's co-operative guilds and in conversations with others in the movement, Makonnen further developed a critique of the movement's complicity with colonialism. Why, for example, did the British cooperative movement denounce imperialism but not 'question the fact that the wholesale side of the business was doing over $£ 20$ million worth of dealings in tea from Ceylon'? Why did it not foster co-operative producers' unions in Ceylon? ${ }^{88}$ Makonnen also took aim at African businessmen who were 'robbing their own people through cocoa and other commodities.' He saw an indigenized form of cooperation as an answer, one that would link 'the high British ideal of morality in the co-operative movement ... with our traditional African form of co-operation.' Like Sankoh, he argued that a politics based on a mere 'demolition of colonialism' was insufficient: 'it wasn't just a question of independence, but how were we to organize our activity thereafter?' ${ }^{89}$ In support of this effort, Sankoh and Makonnen created the apparently short-lived African Co-operative League. ${ }^{90}$

Both men were also involved in the Fifth Pan-African Congress in Manchester in $1945 .{ }^{91}$ Makonnen provided funding for the event and served as a local host. ${ }^{92}$ He was also an official delegate, representing the International African Service Bureau, as was Sankoh, representing

\footnotetext{
${ }^{82}$ Makalani, In the Cause of Freedom, 209; Leslie James, George Padmore and Decolonization from Below: Pan-Africanism, the Cold War, and the End of Empire (Basingstoke: Palgrave Macmillan, 2015), 30; Adi and Sherwood, Pan-African History, 118.

${ }^{83}$ Makonnen, Pan-Africanism from Within, 133-34.

${ }^{84}$ Makonnen, Pan-Africanism from Within, 133; Adi and Sherwood, Pan-African History, 119; Munro, The Anticolonial Front, 52-3; Sherwood, Manchester and the 1945 Pan-African Congress, 14, 53-5.

${ }^{85}$ C. Magbaily Fyle, Historical Dictionary of Sierra Leone (Lanham, MD: Scarecrow Press, 2006), 169-70.

${ }^{86 ‘}$ College Students,' The Co-operative Review 14, no. 5 (May 1940).

${ }^{87}$ Laminah Sankoh, 'Appeal to British Co-operators,' The Stokehole (1940), 12-14.

${ }^{88}$ Makonnen, Pan-Africanism from Within, 134. See Erika Rappaport, A Thirst for Empire: How Tea Shaped the Modern World (Princeton: Princeton University Press, 2017), 151.

${ }^{89}$ Makonnen, Pan-Africanism from Within, 135.

${ }^{90}$ Makonnen, Pan-Africanism from Within, 133.

${ }^{91}$ Munro, The Anticolonial Front, 44, 60; Adi and Sherwood, Pan-African History, ix.

${ }^{92}$ Munro, The Anticolonial Front, 53; Sherwood, Manchester and the 1945 Pan-African Congress, 28, 30; Pan-African Congress Press Release No. 7, AC8 GB3228 34/01/08, Pan-African Congress, Box 70, Race Relations Archives, Manchester Central Library (henceforth RRAMCL).
} 
his Sierra Leonean integrationist project, the People's Forum. J. C. de Graft Johnson, who would be a major supporter of the Ghanaian cooperative movement, represented the Coloured Peoples Association of Edinburgh. ${ }^{93}$ The cooperative movement was woven through the conference's proceedings. The Pan-African Federation included the 'encouragement among African peoples of Consumers' and Producers' cooperatives' among its stated goals. ${ }^{94}$ The representative of the Trade Union Congress of Nigeria demanded, among other things, 'a Co-operative Movement to oust the combines in Africa. ${ }^{\text {'95 }}$

\section{The college and the colonial office}

The Pan-African Congress of 1945 was probably the zenith of the Cooperative College's connection with organized anti-colonialism. After 1945, the College, now located at a new, larger campus at Stanford Hall in Loughborough, was increasingly linked with the Colonial Office. ${ }^{96}$ From site of robust critique of empire and capitalism, it became a kind of nongovernmental organization paid to conduct outsourced training of colonial and neo-colonial bureaucrats.

In 1946, representatives of the Colonial Office visited Stanford Hall and recommended the creation of 'a special course for colonial students. ${ }^{97}$ This course was part of the wider project of building a 'unified colonial service,' which led the Colonial Office to develop courses at Oxford, Cambridge, and LSE from the 1930s and, in the 1940s, to fund a range of new scholarships, increasing the number of African and West Indian students in British universities. ${ }^{98}$ The Cooperative College worked closely with the Colonial Office on the course. B. J. Surridge, the Adviser in Co-operation to the Secretary of State for the Colonies, undertook some of the core teaching and co-authored one of the main textbooks. ${ }^{99}$ In 1950, the course was expanded from two terms to three, with the addition of guest lecturers and a seminar in which the students would choose a 'selected problem of Colonial co-operative development' on which they would 'report with recommendations for future action.' ${ }^{\prime 100}$ In the 1951-1952 academic year, eleven students attended through Colonial Office sponsorship, plus two more students from the colonies who were sponsored by other organizations. They attended lectures on a range of subjects including co-operative organization, the economics of cooperation, and colonial cooperative law. In addition, the students visited co-operative sites in England, Scotland, and Wales. At the end of the year, for the first time, the students in colonial cooperation sat College examinations alongside the home students. ${ }^{101}$

Between 1948 and 1954, student figures show that colonial students predominantly studied on the colonial course, while British and other overseas students mainly did not. At the same time, they remained integrated into the social life of the college, in ways that sometimes seem infantilizing given that most colonial students were adults in their thirties or forties. In addition to their

\footnotetext{
${ }^{93}$ Pan-African Congress Press Release No. 5, AC7 GB3228 34/01/07, Pan-African Congress, Box 70, RRAMCL.

${ }^{94}$ 'What is the Pan-African Federation?', flyer (undated), AC6 GB3228 34/01/06, Pan-African Congress, Box 70, RRAMCL.

${ }^{95}$ Pan-African Congress Press Release No. 9, AC9 GB3228 34/01/09, Pan-African Congress, Box 70, RRAMCL.

${ }^{96}$ Robert Snowball Birch, 'The Story of the Co-operative College,' The Stokehole (1944), 5; 'New College Purchased,' The Co-operative Review 14, no. 4 (Apr. 1945), 51.

${ }^{97}$ R.A.D., 'Colonial Co-operation,' The Co-operative Review 20, no. 11 (Nov. 1946), 213.

${ }^{98}$ Marc Matera, 'Colonial Subjects: Black Intellectuals and the Development of Colonial Studies in Britain,' Journal of British Studies 49, no. 2 (April 2010), 388-418, 391, 393; Memorandum on Co-operation in the Non-Self-Governing Territories under United Kingdom Administration, CO 852/1360/1, NA.

${ }^{99}$ Co-operative College Fifth Colonial Course - October 1951 to June 1952, CO 852/1360/2, NA. See also Surridge to Adams, 3 Oct 1952, CO 852/1360/4, NA.

${ }^{100}$ Memo, B. J. Surridge, 20 June 1950, CO 852/1360/3, NA [quote]; Secretary of State for the Colonies to Officers Administrating Governments of Mauritius, Gold Coast, Nigeria, Cyprus, Tanganyika, and Trinidad, 26 June 1950 , CO 852/1360/3, NA; Officer administering the government, Gold Coast, to Secretary of State for the Colonies, 19 July 1950 , CO 852/1360/3, NA.

${ }^{101}$ Co-operative College Fifth Colonial Course - October 1951 to June 1952, CO 852/1360/2, NA.
} 
classes, students at Loughborough had access to facilities for various sports such as squash, tabletennis, and hockey, as well as to facilities for 'gramophone recitals.' They were required to assist in the shared tasks of communal life, such as washing up in the dining room and helping in the grounds, to obtain passes for overnight absence, and to make their beds each morning. Alcohol was forbidden in the College. ${ }^{102}$

As in the interwar years, the 'international quality of the College' was seen as one of its greatest attributes, but this was often celebrated in superficial ways: photographs of students in their national costumes,' for example. ${ }^{103}$ Colonial students remarked on the particular character of the College, differentiating it from England in general. Theo Vardon, from the Gold Coast, had been 'very lonely and homesick' in London, but at the College, 'I am very happy for students freely mix and exchange ideas.' Marconi Robinson, from Tobago, described the College as a 'meeting-place almost as international as the United Nations, but one with a spirit of friendship and brotherhood.' ${ }^{104}$

Students on the postwar colonial cooperation course were generally men who had begun careers within the colonial administration. The course was meant to broaden their perspectives and prepare them for further advancement within the cooperative bureaucracy of their territories, and, ultimately, to create a cadre of cooperative leaders who could assist in the general project of economic development and adjustment to global markets. As a 1944 survey of the college stated, these students would return 'to their native lands to serve their own Movements and in some cases act as pioneers of cooperation. ${ }^{105}$ Between 1946 and 1960, using the same methods of aggregation from periodicals and patchy records, I identified seventy-eight students who came from British colonies or recently decolonized nations to the College. West Africa had the greatest representation (12 from Nigeria, 13 from Gold Coast/Ghana), with East Africa also well represented (13 students, of whom nine were from Tanganyika) and a considerable number of students from South Asia and the Caribbean as well. These numbers are indicative of distribution but far from exhaustive. According to the College principal, by 1967, over six hundred students from so-called developing countries, mainly within the Commonwealth, had studied at the College under the post-war scheme. ${ }^{106}$ Students were usually funded by their local governments or by the Colonial Office, which sponsored a select number students for the course. ${ }^{107}$

College Reports on students forwarded to the Colonial Office emphasized qualities of leadership. Rupert Dowden, from British Guiana, attended in 1951-52; his report describes him as 'one of the best students we have had,' 'shrewd and practical' and 'something of a natural leader.' On the other hand, a student from the Gold Coast required further tutelage: 'Is quick witted but as yet jumps too hastily to conclusions. Should make a good man if under good supervision for a time.' ${ }^{108}$

In 1951, the British Council established a joint scholarship with the Co-operative Union in order to provide an opportunity for overseas students working, preferably, within the voluntary co-operative sector to study for a full session at the Co-operative College. ${ }^{109}$ It was awarded to students in specific territories each year, on the advice of the College principal and B.J. Surridge, who seem to have emphasized qualities of leadership, influence, and potential impact

\footnotetext{
${ }^{102}$ Marshall to [new student], August 1952, CO 852/1360/4, NA

${ }^{103}$ R. L. Marshall, 'Report from Stanford, 1948,' Co-operative College Magazine 1, no. 3 (1948), 3 [first quote]; 'From Four Continents,' Spectrum: Magazine of the Co-operative College 1956-57, 21 [second quote]. See also W. P. Watkins, 'The College and its International Influence,' Co-operative College Magazine (1952), 9-10; A College Visitor, 'Colonial Students at Stanford: College Courses Help Towards Self Government,' The Co-operative Review 26, no. 6 (June 1952), 134.

${ }^{104 ‘}$ 'Through Other Eyes,' Co-operative College Magazine 1954, 32.

${ }^{105}$ Robert Snowball Birch, 'The Story of the Co-operative College,' The Stokehole (1944), 4.

${ }^{106}$ R. L. Marshall, 'Twenty-one years on,' Report from the college Spectrum: Magazine of the Co-operative College 1967, 3.

${ }^{107}$ See Hay to Adams, 27 May 1952; Adams to Hay, 13 Feb 1952, CO 852/1360/2, NA.

${ }^{108}$ Co-operation Staff Training Co-operative College Courses Report, CO 852/1360/2, NA.

${ }^{109}$ Announcement of scholarship 1954 and Scarr to Marshall, 17 April 1951, British Council Archives BW1/80, NA.
} 
in their selection process. ${ }^{110}$ In 1952, they awarded the scholarship to Godfrey Paul Kanagaraj, who was working for the Ulu Bernam Co-operative Society Stores Society in Malaya, because he 'seems to be a person of character and initiative and mature enough to benefit from the course.' ${ }^{111}$ They also considered the local prominence of candidates. One student recommended for a scholarship on a summer course in 1954 was a Mr. Omonya from Uganda. Aged 40, he had recently been elected to the Uganda Legislative Assembly, and, as the assistant for the Bursaries Section of the British Council informed the Co-operative Union, 'we understand from his District Commissioner that he is connected with many of the leading families in the district and is a man of considerable influence.' 112

In contrast with the plurality of interwar critiques of colonialism and capitalism, postwar College publications were more likely to endorse a narrative of civilizational progress and tutelage through the means of the cooperative movement, with Britain as a kind of cooperative mothercountry. One British student explained to his overseas comrades: 'you will realise that the suffering of the ordinary people of this country, in the past, was no different to the suffering of your people, past and present.'113 A student from Trinidad agreed, telling a visitor in 1952: 'Perhaps above all we are profiting from Britain's past experience.'114

Such lessons from history were highly selective. The British cooperative movement's historical links with radical politics faded into the background; in its place was the old idea of cooperation as a path to modernity and citizenship that by-passed political unrest. In 1958, Joseph Ademola Ologe, who worked as a Cooperative Inspector in the Nigerian Civil Service, made an argument that could have been cribbed from the discussions of detribalization thirty years before. 'The very rapid advance in education, social services and economic life produced by over fifty years of colonial rule had created a class of educated West Africans who gradually broke away from the social structure in which they were reared. ${ }^{\prime 15}$ Another Nigerian student, A. Ayordinde, who was on the Executive Committee of the Co-operative Union of Eastern Nigeria and the Cameroons and was at the College on a government scholarship, explained that the cooperative movement would assist in jettisoning outmoded ways while preserving what was still useful. ${ }^{116}$

At the same time, the student newspaper continued to publish direct criticism of British policies overseas. Rather than an analysis of extractive colonialism, this now more often took the shape of criticism of British hypocrisy on democracy and free speech. M. M. Tell from Jordan told the student newspaper that while he admires 'our democratic system in Britain [he] wishes that we were as democratic overseas as we are at home. ${ }^{\prime 17}$ Two other students, C. Georghiades of Cyprus and Gervase Ishengoma from Tanganyika, expressed their admiration and surprise at the freedom of speech enjoyed in Britain; their surprise, perhaps, also contains an implicit critique at the lack of such freedom allowed by British administrations in their homelands. ${ }^{118}$ In both narratives of development progress and critiques of British administration, then, democracy came to play an increasingly central conceptual role; it would likewise prove to be a rich terrain for working out the uses the cooperation in postcolonial regimes.

\footnotetext{
${ }^{110}$ S. George West to representative, Federation of Malay, 26 July 1954, British Council Archives BW1/80, NA.

${ }^{111}$ Marshall to Barkworth, 8 Aug. 1952, and J. W. L. Gale, undated letter [quote], British Council Archives BW1/80, NA.

${ }^{112}$ E. M. Hall to L. C. Fox, 25 July 1954, British Council Archives BW1/80, NA.

${ }^{113}$ W. D. Bailey, 'To our Colonial Fellow Students,' Co-operative College Magazine (1952), 29. See also R. Southern, 'International Co-operation,' Co-operative College Magazine (1952), 15.

${ }^{114}$ A College Visitor, 'Colonial Students at Stanford: College Courses Help Towards Self Government,' The Co-operative Review 26, no. 6 (June 1952), 135.

${ }^{115}$ Joseph Ademola Ologe, 'West Africa's Dilemma,' Spectrum (1957-58), 28.

${ }^{116}$ A. Ayordinde, 'An African student explains Tribal Marks,' Co-operative College Magazine (1955), 18.

${ }^{117}$ 'Through Other Eyes,' Co-operative College Magazine (1955), 25.

${ }^{118}$ 'Through Other Eyes,' Co-operative College Magazine (1955), 25; 'As Others See Us,' Co-operative College Magazine (1956), 37.
} 


\section{The uses of cooperation}

The colonial course had been designed to create cohorts of cooperative experts for the colonial bureaucracies. It succeeded in this aim, participating in the broader indigenization of civil services and their eventual decolonization. By the late 1950s, the Co-operative Union reported that 'the majority of people employed' in colonial co-operative departments 'are of local origin, many of whom have been trained at the Co-operative College in Britain. In most instances, however, the senior posts are still held by Europeans. ${ }^{119}$ This, too, would change, as the case of Henri Lewis Camille illustrates. He joined the Mauritius Civil Service in 1936, transferring to the Co-operative Department in 1947. In 1952 he was at Co-operative College on the colonial course, where he praised the 'magnanimity of the British rule' in his country. ${ }^{120}$ His College report described him as a student 'with a very lively mind, original and imaginative,' who 'would derive great benefit from wider experience. ${ }^{121} \mathrm{He}$ became the first Mauritian Registrar of Co-operatives when he succeeded Robert Allan Russel in the role in $1966 .{ }^{122}$

Such careers were possible because, despite their association with colonialism, cooperatives proved to be significant tools for many postcolonial governments, often becoming tightly linked with state initiatives and used to assert a rationalizing, centralizing control over entire industries. ${ }^{123}$ By 1955, the majority of countries represented at the International Co-operative Alliance were nonEuropean. ${ }^{124}$ However, this is not a simple story of postcolonial continuity, as I argue here using the cases of Sierra Leone, Malawi, and Ghana. Cooperative movements were attractive to governments embracing large-scale planned economic development, because they offered a centralized means of accessing rural communities and organizing agricultural production. However, their independent and internationalist tendencies made them difficult to control. Efforts to harness cooperative movements thus reveal the complex relationships between development and democracy as well the diversity of political-economic visions of the future in the early years of independence.

In Sierra Leone, the government actively sidelined efforts to create an independent cooperative movement rather than a bureaucracy. Laminah Sankoh returned to Sierra Leone from Manchester in the early 1940s, founding a newspaper and a political party with the aim of overcoming the rift in the country's politics between the colony's Krio majority and the Indigenous Africans of the protectorate. ${ }^{125} \mathrm{He}$ also founded the non-state, fully voluntary Sierra Leone Aro Co-operative Society. ${ }^{126}$ Herbert M. Awoyo Johnson, an employee of the Colonial Treasury in Freetown, was involved in the Aro Co-operative Society and came to Manchester in 1944 to obtain 'first-hand information on British Co-operation' at the College. ${ }^{127}$ There, he made it clear that Sankoh's integrationist political goals were inseparable from the economic project of cooperation. Awoyo Johnson linked 'conflict and competition as a principle of economic progress' with the 'principle of divided rule,' suggesting that Sierra Leone needed to get away from both principles. ${ }^{128}$ However, Sankoh's political career foundered; significantly, the Aro Co-operative Society ran

\footnotetext{
${ }^{119}$ Co-operation in Other Lands II, 75.

${ }^{120}$ H. L. Camille, 'Mauritius and Co-operation,' Co-operative College Magazine (1952), 16, 47.

${ }^{121}$ Co-operation Staff Training Co-operative College Courses Report, CO 852/1360/2, NA.

${ }^{122}$ Chit Geerjanand Dukhira, History of Mauritius: Experiments in Democracy (Quatre-Bornes: Dukbira, 2002$), 152$.

${ }^{123}$ Andreas Eckert, 'Useful Instruments of Participation? Local Government and Cooperatives in Tanzania, 1940s to 1970s,' The International Journal of African Historical Studies 40, no. 1 (2007): 97-118; Rita Rhodes, Empire and Co-operation: How the British Empire Used Co-operatives in its Development Strategies 1900-1970 (Edinburgh: John Donald, 2012), xi, 72-3; Mo Moulton, 'Not to Nationalise, but to Rationalise? Cooperatives, Leadership and the State in the Irish Dairy Industry 1890-1932,' Irish Economic and Social History (2017).

${ }^{124}$ Watkins, The International Co-operative Movement, 37.

${ }^{125}$ Fyle, Historical Dictionary of Sierra Leone, 170; David Harris, Sierra Leone: A Political History (Oxford: Oxford University Press, 2014), 7, 28; Cole, 'Decolonization and the Rise of Krio Separatism,' in Ojukutu-Macauley and Rashid, Paradoxes of History and Memory in Postcolonial Sierra Leone, 110, 125-27.

${ }^{126}$ Laminah Sankoh, 'Appeal to British Co-operators,' The Stokehole (1940), 13.

${ }^{127}$ H. C. Mansfield, 'Chairman's Page,' The Stokehole (1944), 2.

${ }^{128}$ Herbert M. Awoyo-Johnson, 'The Need for Co-operative Education in West Africa,' The Stokehole (1944), 18.
} 
afoul of the colonial administration in Sierra Leone, 'which declared that [Sankoh] had no authority to use the word cooperative. ${ }^{\prime 29}$ Independent Sierra Leone would go on to have a large cooperative movement sponsored by the government, but the Aro Co-operative Society seems to have faded away. ${ }^{130}$

By contrast, in Nyasaland/Malawi, the cooperatives introduced by the colonial administration were first rejected and then definitively repurposed by African farmers. ${ }^{131}$ Early developments in the colony were in line the emerging pattern of cooperation-as-modular-solution. Nyasaland Governor Harold Kittermaster, having read C.F. Strickland's reports on cooperation, requested advice on the subject in 1936. With funding from the Carnegie Foundation, the Colonial Office sent civil servant H. F. Bingham from Nyasaland to learn about cooperatives in Ceylon, West Africa, and Europe in 1937-38. ${ }^{132}$ This nascent globe-trotting expert returned with a theory that indebtedness was at the root of rural poverty. ${ }^{133}$ Assuming a homogeneity across developing areas that did not exist, he sought to apply the modular solution of cooperation in order to stabilize the labor market and shore up indirect rule by re-directing well-off Africans' energy from anticolonial politics into economic channels instead. Finding little enthusiasm among this population, Bingham expanded his efforts in 1939, allowing for other types of cooperatives and setting up a training program. ${ }^{134}$ Cooperatives in Nyasaland languished during the Second World War but were picked up again under the leadership of the 'development governor' Geoffrey Colby. ${ }^{135}$ Bingham visited the Co-operative College in 1946 and 'returned to Africa with a supply of cooperative literature,' planning to translate it into a local language. ${ }^{136} \mathrm{He}$ argued that local, African initiative was crucial. ${ }^{137}$ However, in reality, African businessmen resisted cooperation when they feared it would not pay or would lead to White dominance, and Bingham remained controlling and mistrustful, refusing permission to societies interested mainly in profit. ${ }^{138}$

In 1951, William Coldrick, the chairman of Britain's Co-operative Party, took a five-week tour of Northern and Southern Rhodesia, Nyasaland, Kenya, Cairo, and Malta as a member of a Commonwealth Parliamentary Association delegation. In Nyasaland, he met Bingham and found him a 'great enthusiast' for cooperation. Despite the assistance provided by the Colonial Office for cooperative development, however, Coldrick was disappointed. The 'able Africans' he met 'spend their whole time demanding political suffrage, and so far as I could see do nothing to help their own people learn the nature of democracy by accepting responsibility.' He distinguishes, here, between the mere form of democracy - political suffrage - and the deeper reality of democracy which is rooted in the kind of responsibility for collective welfare that cooperation was meant to instill. His solution is simultaneously nostalgic for empire and a prefiguring of the patterns of the late twentieth-century aid industry: the British cooperative movement should send 'some of our able young men' to Africa for a few years to encourage cooperatives and thus teach real democracy. ${ }^{139}$ In reality, Nyasaland's cooperatives were absorbed into nationalist politics. In 1953,

\footnotetext{
${ }^{129}$ Fyle, Historical Dictionary of Sierra Leone, 171.

${ }^{130}$ Ralph Gerald Saylor, The Economic System of Sierra Leone (Durham: Duke University Press, 1967), 99-100, 99n20.

${ }^{131}$ McCracken, A History of Malawi, 3.

${ }^{132}$ Joey Power, "Individualism is the Antithesis of Indirect Rule": Cooperative Development and Indirect Rule in Colonial Malawi,' Journal of Southern African Studies 18, no. 2 (June 1992): 317-47, 335; Värlander, 'A Genealogy of Governing Economic Behaviour,' 21.

${ }^{133}$ Värlander, 'A Genealogy of Governing Economic Behaviour,' 59-61.

${ }^{134}$ Power, "Individualism is the Antithesis of Indirect Rule', 318-19 [quote], 338.

${ }^{135}$ Joey Power, Political Culture and Nationalism in Malawi: Building Kwacha (Rochester, NY: University of Rochester Press, 2012), 94-5.

${ }^{136}$ R.A.D., 'Colonial Co-operation,' The Co-operative Review Vol. XX, No. 11 (Nov. 1946), 213.

${ }^{137}$ H. F. Bingham, 'Nyasaland,' Year Book of Agricultural Co-operation, 1949 (Cambridge: W. Heffer \& Sons Ltd., 1949), 319.

${ }^{138}$ Power, "'Individualism is the Antithesis of Indirect Rule", 318, 340, 345.

${ }^{139} \mathrm{~W}$. Coldrick, 'Is federation the solution to the African problem?' The Co-operative News, 13 Oct. 1951, press cutting, CO $852 / 1360 / 5$, NA.
} 
violence broke out over rural complaints, incuding new rules related to conservation, as well as nationalist anger at the threat of federation with Rhodesia. Organizations such as the Kilipula Rice Growers Cooperative Union and other local cooperatives were led and controlled by members of the nationalist Nyasaland African Congress. Cooperatives even provided shelter for illegal meetings and, in at least one case, a cooperative employee assisted a Congressman on the run. ${ }^{140}$

If in Sierra Leone cooperatives remained part of the state apparatus, and in Nyasaland/Malawi they became a site of nationalist resistance, in postwar Gold Coast/Ghana, the significant cooperative sector occupied an intermediate position. As they had been in pre-war era, they were a target of successive administrations interested in control over the lucrative cocoa-growing sector. Yet, because of their local and international clout, the cooperatives retained some ability to resist. Four postwar Co-operative College students-Joseph Obuobi, George Oteng, N.A. Dennis, and Laurence O. Koranteng-used their expertise to different ends in the struggle over the cooperative sector and, more broadly, democratic institutions in independent Ghana. ${ }^{141}$

After the Second World War, cooperatives increased their market share within the cocoa industry. ${ }^{142}$ In 1944, a Cooperative Department was created, shifting oversight of the cooperatives out of the remit of the Department of Agriculture, and the Gold Coast Co-operative Federation 'was formed to control and guide the societies.' ${ }^{143}$ Although the process involved a 'ruthless consolidation,' it made the cooperatives demonstrably successful and thus attractive to non-member farmers. ${ }^{144}$ The department also created a cooperative bank and consumer cooperatives, the latter a direct challenge to foreign firms. ${ }^{145}$

In the midst of this efflorescence, and in the context of the Africanization of the civil service, the Gold Coast cooperative movement sent a large number of students to the Co-operative College. ${ }^{146}$ Some of them were government officials with scholarships. ${ }^{147}$ Others worked at co-operative organizations and were sponsored by the Co-operative Federation. ${ }^{148}$ By 1959, a dozen officers in the Co-operative Department had been trained at the College, and six more who had been trained there worked in the wider movement. ${ }^{149}$ The movement also looked beyond Britain, sending officers for training in Nigeria and Kenya and taking part in visits to places including Israel, Canada, and the Soviet Union. ${ }^{150}$

For the rising nationalist movement centred on Nkrumah and his Convention People's Party (CPP), the cooperative movement was both a threat and an attractive prize. Cooperative leaders kept their distance: George Oteng, for example, became a Progress M.P for Ahafo-Ano, part of the opposition to Nkrumah that was rooted in the cooperative movement. ${ }^{151}$ Having failed to win cooperative organizations over, the CPP sought to build an alternative structure of cocoa farmers and buyers that would sap the power of the cooperatives. They launched the Cocoa Purchasing Company in 1952 as a 'wholly owned subsidiary of the Cocoa Marketing Board. ${ }^{152}$ It was superseded in 1953 by the United Ghana Farmers Council (UGFC), which was declared the

\footnotetext{
${ }^{140}$ Power, Political Culture and Nationalism in Malawi, 116.

${ }^{141}$ Assistant Registrar - Education, Department of Co-operation, Accra, to Marshall, 15 Sept. 1952, CO 852/1360/4, NA.

${ }^{142}$ Young, Sherman, and Rose, Cooperatives and Development, 181.

${ }^{143}$ Miracle and Seidman, Agricultural Cooperatives and Quasi-Cooperatives in Ghana, 8.

${ }^{144}$ Young, Sherman, and Rose, Cooperatives and Development, pp. 181-82.

${ }^{145}$ Stockwell, The Business of Decolonization, 88; Young, Sherman, and Rose, Cooperatives and Development, 182.

${ }^{146}$ Ahlman, Living with Nkrumahism, 8.

${ }^{147}$ A College Visitor, 'Colonial Students at Stanford: College Courses Help Towards Self-Government,' The Co-operative Review 26, no. 6 (June 1952), 134; Co-operation Staff Training Co-operative College Courses Report, CO 852/1360/2, NA.

${ }^{148}$ Assistant Registrar Education, Department of Co-operation, Accra, to Marshall, 15 Sept. 1952, CO 852/1360/4, NA.

${ }^{149}$ Annual Report of the Department of Co-operation for the Year 1958-59 (Accra: Government Printer, 1960$), 10$.

${ }^{150}$ Nat. Yankah, 'Co-operation in the Gold Coast,' Co-operative College Magazine 1950, 38; Annual Report of the Department of Co-operation for the Year 1958-59 (Accra: Government Printer, 1960), 11.

${ }^{151}$ Dennis Austin and Robin Luckham, Politicians and Soldiers in Ghana 1966-1972 (London: Routledge, 2015 [1975]), 148; see Young, Sherman, and Rose, Cooperatives and Development, 5, 183.

${ }^{152}$ Miracle and Seidman, Agricultural Cooperatives and Quasi-Cooperatives in Ghana, 18.
} 
'representative body of the farmers in this country.' ${ }^{153}$ The UGFC was given a subsidy and a building; its share of the cocoa market grew to nearly $24 \%$ in $1959-60$. At the same time, the government began to take steps to bring the cooperatives under the control of the UGFC. ${ }^{154}$

In August 1959, Hon. Kojo Botsio, M.P. addressed the Congress of the Co-operative Movement. In his address, he praised the 'democratic nature of cooperation' and its capacity to produce good leaders. His litany of praise touched, too, on the balance sheet: the $£ 2$ million accrued through share payments and reserves, and the 'impressive assets' acquired, such as 'the buildings of Bank and Marketing Association in Accra and Kumasi, as well as the hundreds of storage sheds which are very prominently in evidence around our countryside.' He called, however, for a reorganization of the movement, which would bring the Trades Union Congress (TUC) and the UGFC into a single alliance with the cooperative organizations, which could also take over the work of the Co-operative Department. The Government, he suggested, would support this work in various ways, including increased grants. ${ }^{155}$

According to the Co-operative Department, although opinion was 'sharply divided,' the Alliance of Ghana Co-operatives 'declined the offer' and was duly superseded in December by a new National Co-operative Council. ${ }^{156}$ Pressure on cooperative leaders to join the party continued, but they regarded the invitation to form a single organization with the TUC and the UGFC as a 'trojan horse,' because of those organizations' close ties with the CPP. Significantly, they resisted, in part, through recourse to the international cooperative movement and its norms, explaining that 'it was against the principles of the cooperative movement to identify itself with any political party,' and the Ghana cooperative movement would be expelled from the International Co-operative Alliance if that principle were violated. ${ }^{157}$

By 1960, however, the pressure had become too much, as the press piled on and bank guarantees were threatened. In August, the Co-operative Association voted to affiliate with the new National Co-operative Council. In September, at an emergency meeting, the leadership of the Association was ousted: President Mark Addo and Secretary George Oteng were replaced by Obese Hayford and N. A. Dennis, respectively. ${ }^{158}$ Dennis took part in the plans for reorganizing the buying and selling of cocoa under the new cooperative organizational system. ${ }^{159}$ Although a committee was set up to advise the government on the future of the cooperative movement, Nkrumah ignored its recommendations. In a Dawn Broadcast on April 8, 1961, he made the United Ghana Farmers Council into the sole licensed buying agent for the Cocoa Marketing Board; four days later, the Ghana Co-operative Marketing Association merged with the UGFC. ${ }^{160}$ Nkrumah also targeted other cooperative institutions. Joseph Obuobi, by then an assistant registrar at the Department of Co-operation, was appointed to work with H.C. Gotts, a bank inspector, to enquire into the Bank of Ghana, where Laurence O. Koranteng was the Assistant Manager. The Gotts Enquiry, as it was known, 'made recommendations for the improvement of the operations of Bank,' which was nonetheless closed down in November 1960. ${ }^{161}$ By April 1961, the Department of Cooperatives had also been abolished, and the cooperatives' assets were confiscated. The international cooperative movement seems to have been sidelined as well. Although Co-operative College economics tutor Wynne Davies

\footnotetext{
${ }^{153}$ Report of the Commission of Enquiry into the Circumstances leading to the take-over by the erstwhile United Ghana Farmers Council Co-operatives of the Business and Assets of the Former Co-operative Societies Part I. Undated, 4. Hereafter Report of Commission of Enquiry (Take-over).

${ }^{154}$ Young, Sherman, and Rose, Cooperatives and Development, 184-85.

${ }^{155}$ Report of Commission of Enquiry (Take-over), 215-17.

${ }^{156}$ Annual Report of the Department of Co-operation for the Year 1959-60 (Accra: Government Printer, 1961 ), 10.

${ }^{157}$ Report of Commission of Enquiry (Take-over), 5.

${ }^{158}$ Report of Commission of Enquiry (Take-over), 6-8.

${ }^{159}$ Report of Commission of Enquiry (Take-over), 11.

${ }^{160}$ Report of Commission of Enquiry (Take-over), 13-4.

${ }^{161}$ Report of Commission of Enquiry (Take-over), 23.
} 
left his position in order to take a new job at the Kwame Nkrumah University of Science and Technology in Ghana in 1961, his gesture was exceptional. ${ }^{162}$ The secretary of the British Co-operative Union travelled to Ghana on a fact-finding mission and 'was arrested as a spy and expelled from the country.'163

The subsequent Commission of Enquiry rooted these moves in economic interest: they gave the government 'virtual control of the farming community in this country,' allowing them to set prices without facing opposition. ${ }^{164}$ By 1960-61, the cocoa cooperatives had a 30\% share in the cocoa market and were, for a time, 'the largest single buying agent. ${ }^{165}$ The UGFC operated hierarchically and the Commission of Enquiry investigated allegations of fraud and corruption in connection with its work. ${ }^{166}$

Scholars of the cooperative movement in Ghana have argued that the dissent and disaffection sown among cocoa farmers by the take-over, as well as the broader economic crisis, ultimately undermined Nkrumah's regime. ${ }^{167}$ He fell from power in 1966, and in the aftermath, the cooperative movement was briefly revitalized. That summer, a committee led by de Graft-Johnson found that farmers were 'alienated' by the UGFC and recommended returning to a system that included a role for the cooperatives. ${ }^{168}$ This was furthered by a Commission of Enquiry that, in 1968-69, examined the takeover by the UGFC of the various cooperative organizations. ${ }^{169}$ The four former College students gave substantial evidence both through testimony and submitted documents. The Commission relied on the evidence given by Koranteng and Obuobi, in particular, to challenge the conduct of the liquidator who had overseen the forced take-over. ${ }^{170}$ Oteng and Dennis also gave evidence about the furniture and equipment seized when the UGFC took over the office and other buildings of the Ghana Co-operative Marketing Association. ${ }^{171}$

Ultimately, the new government accepted the Commission's findings that the take-overs were 'irregular and unlawful' and rooted in political motivation. ${ }^{172}$ They designated funds for various purposes to repair the damage, from re-establishing loans to cocoa farms to re-starting the Cooperative Bank. ${ }^{173}$ The cooperative movement reoccupied former offices and premises and returned to business. ${ }^{174}$ Obuobi returned to his post as Registrar of Cooperative Societies; he and Oteng, as secretary of the Ghana Co-operative Marketing Association, attended the AfroAsian Rural Reconstruction Organisation in South Korea. ${ }^{175}$ Dennis became the deputy managing director of the Produce Buying Agency, Ltd. ${ }^{176}$ Ultimately, the reconstituted cooperative movement suffered from a lack of resources and was finally abolished, possibly as the scapegoat for higher government corruption, in $1977 .{ }^{177}$ However, the careers of Oteng, Obuobi, Koranteng,

\footnotetext{
${ }^{162}$ Brian J. Rose, 'Our Loss is Ghana's Gain,' Spectrum: Magazine of the Co-operative College (1961-62), 29.

${ }^{163}$ Birchall, The International Co-operative Movement, 57.

${ }^{164}$ Report of Commission of Enquiry (Take-over), 18; Ahlman, Living with Nkrumahism, 132-33.

${ }^{165}$ Young, Sherman, and Rose, Cooperatives and Development, 182.

${ }^{166}$ Miracle and Seidman, Agricultural Cooperatives and Quasi-Cooperatives in Ghana, 31, 35; Report of Commission of Enquiry (Take-over), 61.

${ }^{167}$ Young, Sherman, and Rose, Cooperatives and Development, 186; Miracle and Seidman, Agricultural Cooperatives and Quasi-Cooperatives in Ghana, 2.

${ }^{168}$ Miracle and Seidman, Agricultural Cooperatives and Quasi-Cooperatives in Ghana, 36.

${ }^{169}$ Report of Commission of Enquiry (Take-over), 2.

${ }^{170}$ Report of Commission of Enquiry (Take-over), 31, 110-11.

${ }^{171}$ Report of Commission of Enquiry (Take-over), 43-5.

${ }^{172}$ White Paper on the Report of the Commission of Enquiry into the circumstances leading to the take-over by the Erstwhile United Ghana Farmers' Council Co-operatives of business and assets of the former co-operative societies (Accra: Ghana Publishing Corporation, undated), 2.

${ }^{173}$ White Paper on the Report of the Commission of Enquiry, 3.

${ }^{174}$ Young, Sherman, and Rose, Cooperatives and Development, 190.

${ }^{175}$ Ghana News Vol. 5-6 (Embassy of Ghana, 1968).

${ }^{176}$ R. A. Kotey, C. Okali, and B. E. Rourke, eds., The Economics of Cocoa Production and Marketing: Proceedings of the Cocoa Economics Research Conferences, Legon, April 1973 (Legon: University of Ghana, 1974).

${ }^{177}$ Young, Sherman, and Rose, Cooperatives and Development, 191-92, 201.
} 
and even Dennis suggest that the Ghanaian cooperative movement was, during its existence, a site of resistance and debate over the nature of postcolonial democracy.

Like later initiatives like community development or microfinance, cooperation was internationalist movement that both championed democratic local empowerment and ensured that such empowerment seemed to be continually postponed. The Co-operative College, like the British cooperative movement, contracted in the late twentieth and early twenty-first centuries; the formal international courses ended in 1997 and the Loughborough campus was sold off in 2001. However, the College continues to exist and to take part in development efforts, such as the Coop Africa project of 2008-11. Although currently in a period of financial uncertaintly and restructuring, the College's commitment to an internationalist vision and its participation in global development trends continue. ${ }^{178}$

Development and democracy were both central to the visions of a post-imperial world that came into being in the middle decades of the twentieth century. The Co-operative College, sometimes in partnership with the Colonial Office, promoted cooperation as a means not only to organize colonial economies more effectively but also to transform colonial subjects into more perfect subjects of a new world order. Its students were imagined as the foot soldiers of the cooperative movement, personal vectors of continuity across the postcolonial rupture. However, they were always more than that. Critics of colonialism while at the College, they made use of the cooperative movement in diverse and unpredictable ways, and in so doing, they became world-makers themselves. As an international network that transcended both national and imperial structures, the cooperative movement could, at least temporarily and contingently, provide a point of leverage against both.

Dr Mo Moulton is Senior Lecturer in the History of Race and Empire at the University of Birmingham.

\footnotetext{
${ }^{178}$ Susan Press, 'A chequered past: What has happened to the Co-op College?' Co-op News, 3 June 2021, accessed 23 June 2021 via https://www.thenews.coop/154924/topic/education/a-chequered-past-what-has-happened-to-the-co-op-college/
}

Cite this article: Moulton M. 2022. Co-opting the cooperative movement? Development, decolonization, and the power of expertise at the Co-operative College, 1920s-1960s. Journal of Global History 17: 418-437, doi:10.1017/S1740022821000279 